\title{
A FRAMEWORK TO ANALYZE AFFORDANCES WHEN USING BIG DATA AND ANALYTICS IN ORGANIZATIONS: A PROPOSAL
}

\author{
LUISA M. STRAUSS ${ }^{1}$ \\ https://orcid.org/0000-0002-0468-3086 \\ NORBERTO HOPPEN ${ }^{1}$ \\ (D) https://orcid.org/0000-0003-1827-8695
}

To cite this paper: Strauss, L. M., \& Hoppen, N. (2019). A framework to analyze affordances when using big data and analytics in organizations: A proposal. Revista de Administração Mackenzie, 20(4). doi:10.1590/1678-6971/eRAMR190182

Submission: Nov. 29, 2018. Acceptance: Feb. 20, 2019.

1 Universidade do Vale do Rio dos Sinos (Unisinos), Porto Alegre, RS, Brazil.

\section{(cc) BY \\ This is an open-access article distributed under the terms of the Creative Commons Attribution License.}

\footnotetext{
This paper may be copied, distributed, displayed, transmitted or adapted if provided, in a clear and explicit way, the name of the journal, the edition, the year and the pages on which the paper was originally published, but not suggesting that RAM endorses paper reuse. This licensing term should be made explicit in cases of reuse or distribution to third parties. It is not allowed the use for commercial purposes.

Este artigo pode ser copiado, distribuído, exibido, transmitido ou adaptado desde que citados, de forma clara e explícita, o nome da revista, a edição, o ano e as páginas nas quais o artigo foi publicado originalmente, mas sem sugerir que a RAM endosse a reutilização do artigo. Esse termo de licenciamento deve ser explicitado para os casos de reutilização ou distribuição para terceiros. Não é permitido o uso para fins comerciais.
} 


\section{ABSTRACT}

Purpose: The article presents the development of a framework to analyze the use of big data and analytics in organizations. The framework is based on affordance theory and actor-network theory (ANT).

Originality/value: Big data and analytics are a set of tools and techniques that are not new, but recently have received much attention from the media and academia. The media promotes big data and analytics while the academia addresses the fact that there are still implementation obstacles and the process of using big data analytics is not well understood. Design/methodology/approach: We used a qualitative approach, in the form of a theoretical essay. We analyzed papers that related affordance theory with IT and, in particular, with big data and analytics. Further, in order to create the resulting framework, an illustrative case study was conducted.

Findings: Affordance theory, allied to the translation concept of ANT, can be useful when analyzing the process of using big data and analytics in organizations, because it contemplates individual and organizational aspects, covering the perception of utility, necessary sociotechnical transformations in processes, people and structures, actual use and organizational effects. As the main contribution, we proposed a framework that includes elements of translation to guide future research.

\section{KEYWORDS}

Big data. Analytics. Affordances. Actor-network theory. Framework. 


\section{INTRODUCTION}

Big data and analytics, although not recent techniques (Boyd \& Crawford, 2012; Chen, Chiang \& Storey, 2012; Davenport, 2013), have been receiving more and more attention from the media specialized in information technology (IT) and from the academia. Evidence of this is the inclusion of topics including analytics, big data and data science in the main IT conference programs promoted by the Association of Information Systems (AIS) worldwide, and by National Association for Graduate Studies and Research in Management (Associação Nacional de Pós-Graduação e Pesquisa em Administração - Anpad) in Brazil.

Davenport (2013) considers that we are in the age of Analytics 3.0, where organizations use data analysis tools, such as business intelligence (BI), not only for their operational efficiency but also to deliver new products and services. This means a rupture in how data should be analyzed and used (Abbasi, Sarker, \& Chiang, 2016; Davenport, 2013).

Making use of big data analytics is also seen as a need to remain competitive in the marketplace (Davenport, 2013). According to PWC (2017), executives seek to make decisions in a shorter time but admit that organizations are not ready for it. Gartner states that only $15 \%$ of organizations have actually implemented big data projects in 2015 (CIO, 2016).

The promise of big data has also created a kind of mythology around the subject (Couldry, 2014). It is as if algorithms could, on their own, explain knowledge in a previously unimagined form, with objectivity and accuracy (Boyd \& Crawford, 2012). For Boyd and Crawford (2012), however, using big data is subjective: it requires knowing how to collect data, aggregate it and perform consistent analysis. To do so, organizations must prepare themselves (Ross, Beath, \& Quaadgras, 2013), which includes people, technology and culture (Germann, Lilien, \& Rangaswamy, 2013). This indicates that there are challenges to be overcome, at the level of both individuals and organizations, when adopting big data and analytics tools.

Despite the growing interest among organizations in using big data analytics and the academy in studying this use, the organizational dimension is not well explored (Tian, 2017), nor is the use process (Dremel, Herterich, $\&$ Spottke, 2017). To understand this process, affordance theory (Gibson, $1977,1986)$ may be useful, since it is adequate to understand the effects of IT use from a non-deterministic point of view (Hansen \& Flyverbom, 2015; Markus \& Silver, 2008). Individuals or organizations with different goals may have different outcomes when using the same tool or technology, or by 
simply appropriating different forms of their characteristics (Leonardi, 2013). For Leonardi (2011), affordance theory provides the basis for analyzing the imbrication between humans and technology, which results in organizational routines. Still, how this occurs when using big data and analytics has not been fully investigated, while its use may be distinct from the deployment of other types of mandatory IT tools.

Considering the challenges and possibilities afforded by big data and analytics tools, methods and techniques, the following research question was established: how are affordances actualized when using big data and analytics in organizations? Thus, it is necessary to examine the use of big data and analytics for decision-making. This type of task is probably more flexible than industrial processes or business processes, while the use and adoption of big data and analytics are possibly optional. According to Leonardi (2011), this should result in different forms or levels of achievement of affordances than those already investigated in IT.

To answer the research question, in the following section, a literature review is presented, explaining affordance theory and its evolution in the area of IT, conceptualizing big data and analyzing research that has already used this theory in the context of big data and analytics. Section 3 discusses the relationship between big data and affordance theory. Section 4 describes a case in which the proposed analysis framework is preliminarily verified. Finally, the paper offers a framework to guide future studies.

\section{LITERATURE REVIEW}

The paper draws on different bodies of literature: the Web of Science, proceedings of the two last editions of the Americas Conference on Information Systems (AMCIS), International Conference on Information Systems (ICIS) and European Conference on Information Systems (ECIS), the Scientific Periodicals Electronic Library (Spell), proceedings of the two last editions of the National Association for Graduate Studies and Research in Management (EnAnpad), and seminal papers and literature reviews on affordances and big data analytics.

References appropriate to an understanding of affordance theory were divided according to the following categories: seminal articles, use of theory in IT and information systems, most cited papers, and use of affordance theory in big data and analytics research. These papers refer to an advanced version of the theory, which goes beyond its mere application.

In order to conceptualize big data and analytics, we selected papers such as reviews, editorials, opinions and an influential article on the subject: an 
editorial of the Journal of the Association of Information Systems (Abbasi et al., 2016). To derive a business perspective on the subject, we selected a leading author in the area of information management and big data (Davenport, 2013 , 2014). The possibilities of using big data and analytics in IT research were identified from Müller, Junglas, Brocke, and Debortoli (2016). Müller et al.'s (2016) work was chosen because the authors raised questions about perceptions and intentions when using results. Boyd and Crawford (2012) presented a critical reading on the possibilities of big data. Finally, in the Brazilian literature, the papers of Coimbra and Chimenti (2018) and Luvizan, Meirelles and Diniz (2015) were also analyzed to complement the conceptualization.

The themes described above are developed in the next sections: section 2.1 describes affordance theory based on its original conception. The development of this theory in the area of IT is considered in section 2.2. Section 2.3 discusses the concept of big data and analytics. Finally, in section 2.4 , we analyze what has already been investigated about big data and affordance theory.

\subsection{Affordance theory}

Affordance theory has its origins in ecological psychology (Leonardi, 2013; Markus \& Silver, 2008). The theory was proposed by Gibson (1977, 1986) to understand the behavior of animals, including humans, in their environments. The noun affordance was coined by Gibson $(1977,1986)$ himself from the verb to afford, which means to provide.

Affordances are possibilities provided by an object to an animal within an environment, such as shelter, food or water. In this way, it implies complementarity between these three elements. In addition, other animals have affordances: cooperation, struggle, communication and so on (Gibson, 1986).

According to Gibson (1986), we cannot always differentiate between the isolated characteristics of an object; this is not necessary, because what attracts our attention is what we can do with it. For example, when looking at a chair, what we perceive in terms of usability is that it allows one to sit down. However, in another context, the same chair allows you to climb up to reach an object that is on a high shelf.

The affordance of something does not change as the need of observer changes. The observer may or may not perceive or attend to the affordance, according to this need, but the affordance, being invariant, is always there to be perceived (Gibson, 1986, p. 139).

This view seems contradictory and is considered ambiguous by several 
authors (Wang, Wang, \& Tang, 2018). If affordances are invariant, they appear to be features of the object. On the other hand, there has to be a perception of affordances which is dependent on what the animal can or cannot do. It is this dynamic that leads to the perception of affordances and, more specifically, to the use of the object.

The process of perceiving affordances is not exempt from judgment: it is the observer who judges whether the affordance will benefit or harm him. In order to be perceived, it is necessary that information about the object, surface or environment is available, that is, the perception is related to what is being observed and what the observer is able to do. In this way, the available information is fundamental to the perception of its affordances. An object may exactly look like what it is capable of providing, while others may have hidden affordances. Considering that the environment and other humans can provide us with information, it is possible to state that the affordances of an object can be verified from communication processes or other people's behavior.

In addition, artifacts can be designed so that their affordances are perceived (Norman, 1999). For Leonardi (2011, p. 153), “affordances and constraints are constructed in the space between human and material agencies". The author further states that, "as people attempt to reconcile their own goals with the materiality of a technology, they actively construct perceptual affordances and constraints" (Leonardi, 2011, p. 154). Thus, the actor can seek new uses in a certain object, even without having to immediately perceive his affordances. Although the term affordances is being used too simplistically (Parchoma, 2014), meaning possibilities, the theory has a value when used to analyze how and why things happen, and not just what (Volkoff \& Strong, 2013).

In IT, although the theory was adopted late on (Wang et al., 2018), it is being used as a means to find a middle ground between technological determinism and social constructivism, (Hutchby, 2001; Klecun, Hibberd, \& Lichtner, 2016; Markus \& Silver, 2008; Wang et al., 2018), as well as to explain the symbiosis between IT and organization (Zammuto, Griffith, Majchrzak, Dougherty, \& Faraj, 2007). In this sense, affordance theory has been adapted to analyze the relationship between users, groups, and organizations as the "animal" and technological artifacts as the "object". The following section reviews relevant studies and how they contribute to the evolution of the theory.

\subsection{The use and evolution of the affordance theory in IT}

Hutchby (2001, p. 444) was the first author to suggest the use of 
affordance theory in the area of IT, stating that "technology can be understood as artifacts which may be both shaped by and shaping of the practices humans use in interaction with, around and through them". He also argued that the dichotomy between what is technical and what is social needs to be challenged because technical and social aspects are not in fact separate. Following this line of reasoning, Latour (2012) suggests that objects and, by extension, IT artifacts, grant, permit, suggest, influence and enable actions. Therefore, as suggested by the actor-network theory (ANT), the association between artifacts and humans, as human and nonhuman actors, must be considered. Likewise, affordances are relational, that is, they depend on the artifact and its materiality in relation to the human actor.

Zammuto et al. (2007) extended this idea by operationalizing theory as a way to understand the modifications that organizations suffer when using IT. For these authors, affordances allow us to understand the relationship between technical and organizational characteristics, which allow us to create new possibilities for action, as well as affecting both the organizational arrangement and the functions. IT affordances can still be seen as mechanisms that generate organizational outcomes and arrangements (Volkoff \& Strong, 2013).

"Possibilities of action are not given, but depend on the intent of the actors enacting them" (Zammuto et al., 2007, p. 752). For Zammuto et al. (2007), affordances, in the organizational dimension, depend as much on the functionalities and characteristics of the technological artifact as on the experiences, processes, routines and other social aspects of the organization. It is not possible to approach complex technology without considering the conditions, or social arrangement, in which it is inserted or being used. Therefore, the use of affordance theory allows researchers to analyze the relationship between technical characteristics and the social environment and how they are intertwined.

Hutchby (2001) also makes it clear that affordances are both possibilities and constraints that a technology imposes, in terms of how they can be interpreted or perceived. Thus, there may be differences in the possibilities of meaning and the possibilities of use, as well as different affordances for the same artifact (Leonardi, 2011).

In organizations, it is necessary to explore at what levels entities and properties emerge. "We do this by noting that an affordance, as an emergent property of the relationship between an object (IT artifact) and an actor, can arise from complex objects and organizational actors" (Volkoff \& Strong, 2013, p. 829). IT artifacts are complex entities, and the possible arrangements also generate new relationships. Moreover, in the same artifact-actor 
relationship, several affordances may emerge.

On the other hand, affordances can never be brought to the real world, that is, actualized. Actualized affordances relate to the actual actions that actors perform, utilizing one or more affordances of a technology, with a view to an objective or immediate outcome (Strong et al., 2014). For Strong et al. (2014), IT has affordances, coupled with the objectives of human actors, but only as action potentials, according to Gibson's $(1977,1986)$ proposal, and are embedded in an organizational context. These affordances, at some point, are perceived and used (Leonardi, 2011). The use or actualization of affordances takes place through an iterative process: as they are performed, the result is evaluated, adjusted if necessary, and can feedback the existing affordances.

In addition, this process is occurring at the individual and organizational levels. From the individual objectives, the possibilities of the tool are perceived and the individual begins to use it as well as perceive its restrictions. Each individual has a different journey. The immediate results of each use are evaluated and adjustments can occur. If there is consistency between the immediate results, their extent and the alignment between people and process, they become organizational results. They can be actualized, for example, in the form of changes in activities and processes. Finally, from these immediate results, the organizational objectives are reached or modified (Strong et al., 2014). In order to capture this dynamic and adopt a process view, Pozzi, Pigni, and Vitari (2014) adapted the framework originally developed by Bernhard, Recker, and Burton-Jones (2013), shown in Figure 2.2.1.

(Figure 2.2.1)

\section{AFFORDANCES THEORETICAL FRAMEWORK}

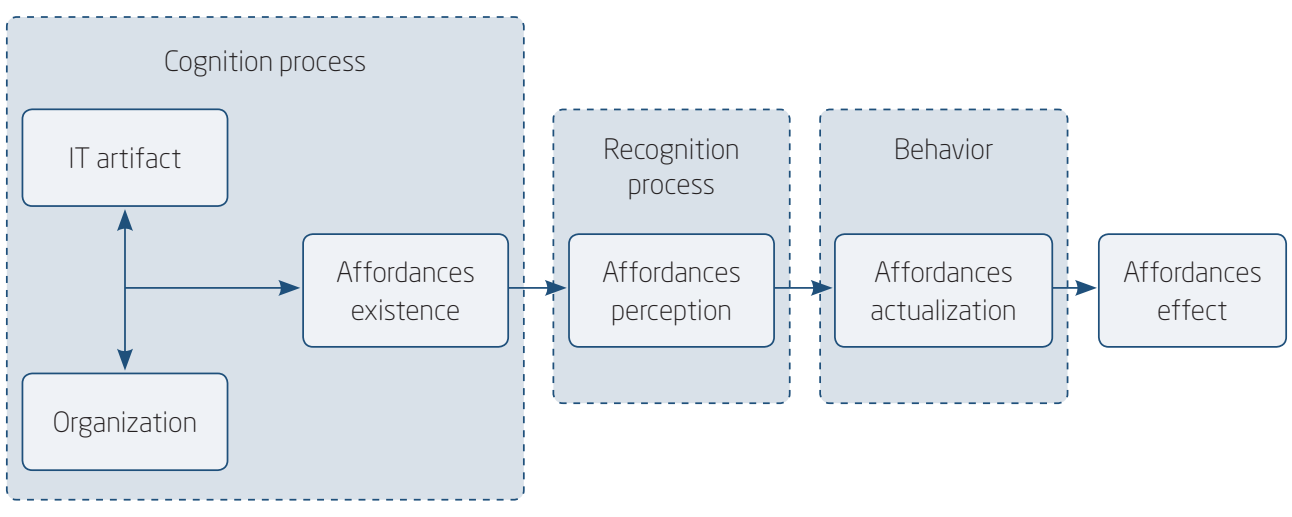




\section{Source: Pozzi et al. (2014).}

In addition to the process shown above, the framework illustrates the constructs of affordances developed in the area of IT (existing, perceived and actualized affordances and affordances effects), which allow us to analyze how and why this process occurs (Volkoff \& Strong, 2013). The existence and perception of affordances are characteristics as well as processes already defined in the original theory proposed by Gibson $(1977,1986)$. However, there is a need to recognize and perceive the affordances of an IT artifact. Already, the actualization of affordances concerns the process of using and interacting with the artifact and potentializing its affordances (Strong et al., 2014). Finally, the affordance effect is the organizational result from the use of the IT artifact. Big data and analytics represent the IT artifact under analysis in this paper, whose concepts are developed in the next section.

\subsection{Big data and analytics}

Big data, according to Davenport (2014), have been summarized in terms of " 5 Vs": volume, variety, velocity, veracity, and value. In other words, big data are data available in large volumes, in many formats and on an ongoing basis, which need to have their authenticity checked for value. Luvizan et al. (2015) understand that the definition of big data should be evaluated in each context. Although the term emphasizes size (big), this is not the main challenge of big data (Abbasi et al., 2016; Boyd \& Crawford, 2012; Davenport, 2014). Abbasi et al. (2016) point out that it is not just about adding scale, variety, speed or noise (veracity) to the data, or simply having the technologies for doing this, but a new way of managing the collection, analysis, and interpretation of the data.

The term big data analytics, in turn, is defined as the "statistical modeling of large, diverse, and dynamic data sets of user-generated by user content and digital traces" (Müller et al., 2016, p. 1). If extended to any kind of content, the concept is more aligned with that of Chen et al. (2012), for whom this is a field within the larger BI and analytics (BI\&A) topic.

BI\&A began in the 1990s, based on BI technologies, in particular, data warehouse and other related processes, which allowed for the analysis of structured data from various sources in a graphical format and with possibilities for statistical analysis and data mining. With the evolution of the use of the Web, external and unstructured data began to be added and, since 2010, data has been generated by mobile devices and the Internet of Things, which Chen et al. (2012) call BI\&A 3.0 and Davenport (2013) calls 
Analytics 3.0.

To capture this spectrum of definitions, our article uses the term big data and analytics to include both traditional BI tools and other analytics fields and tools, such as text, Web and mobile analytics. Thus, big data and analytics is defined as a set of processes, technologies, techniques and methodologies used to collect, store, process, analyze and make available information for decision-making. It contains technical, organizational cultural elements and can be seen as a phenomenon (Boyd \& Crawford, 2012).

This phenomenon, according to the authors, comes from the interaction between IT, the possibilities of analysis and the mythology involved. The latter approaches the belief that, from big data and analytics, reliable, objective and accurate information will be generated, which otherwise would not be possible. On the other hand, Müller et al. (2016) emphasize that, due to the wide variety of algorithms used (Coimbra \& Chimenti, 2018), they may be incomprehensible to decision makers and could be seen as "black boxes", and therefore their results are not used by them.

Abbasi et al. (2016) indicate how the role of organizational culture, the effects on cognition and usability, the adoption of big data technology and the results of its use can support big data research. These themes are aligned with affordance theory and with actualization of affordances (Dremel et al., 2017).

\subsection{Relationship between affordances and big data and analytics in the reviewed literature}

Papers that use affordance theory, in the specific context of big data and analytics, were analyzed according to the following questions:

- What is the concept of affordance considered?

- What is the concept of big data or analytics being employed?

- What is the use type of big data or analytics?

- What use step is being analyzed (adoption, use or results)?

- Is the study conceptual or applied?

Figure 2.4.1 summarizes the analyzed literature in relation to these questions. 


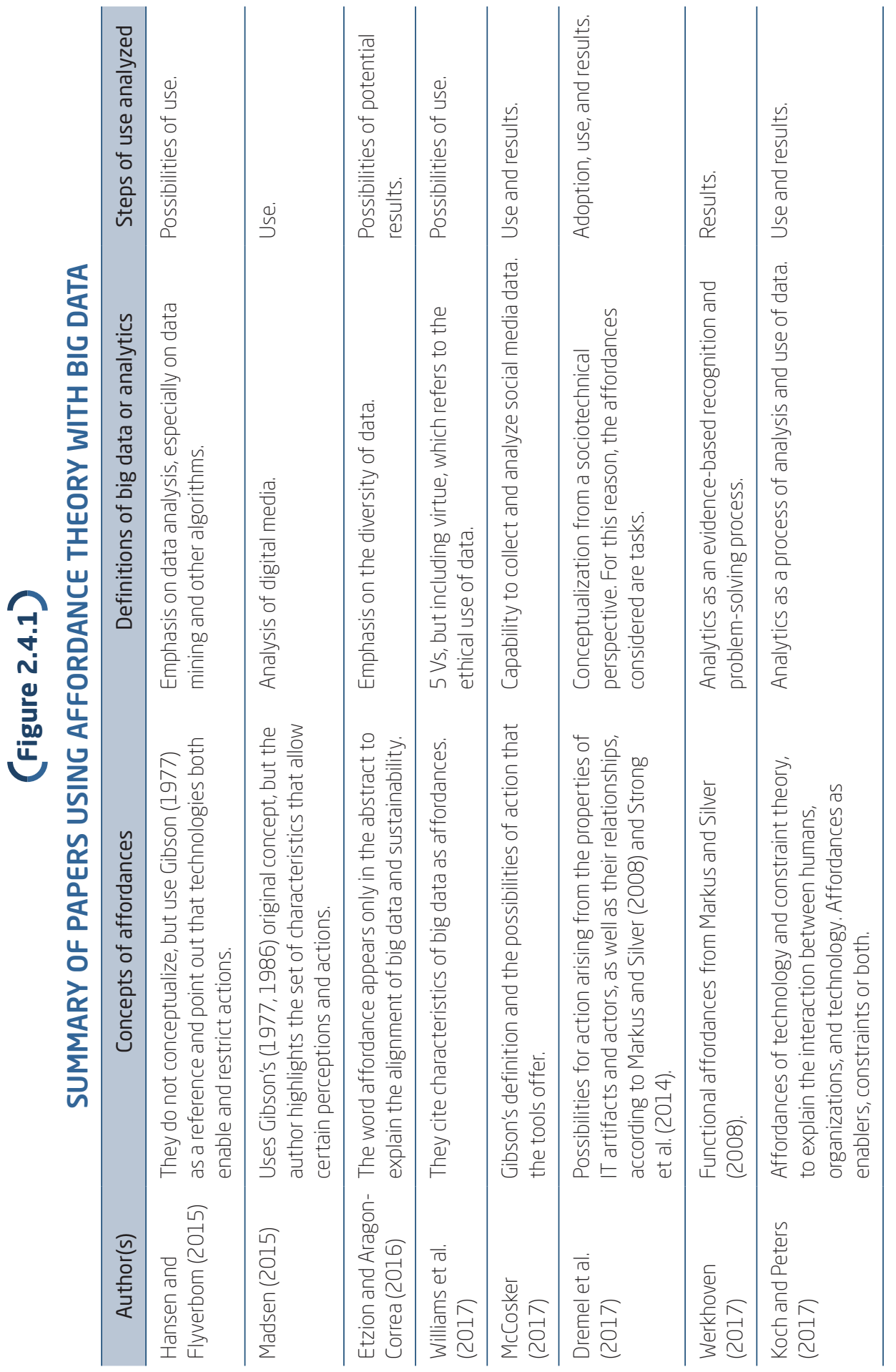




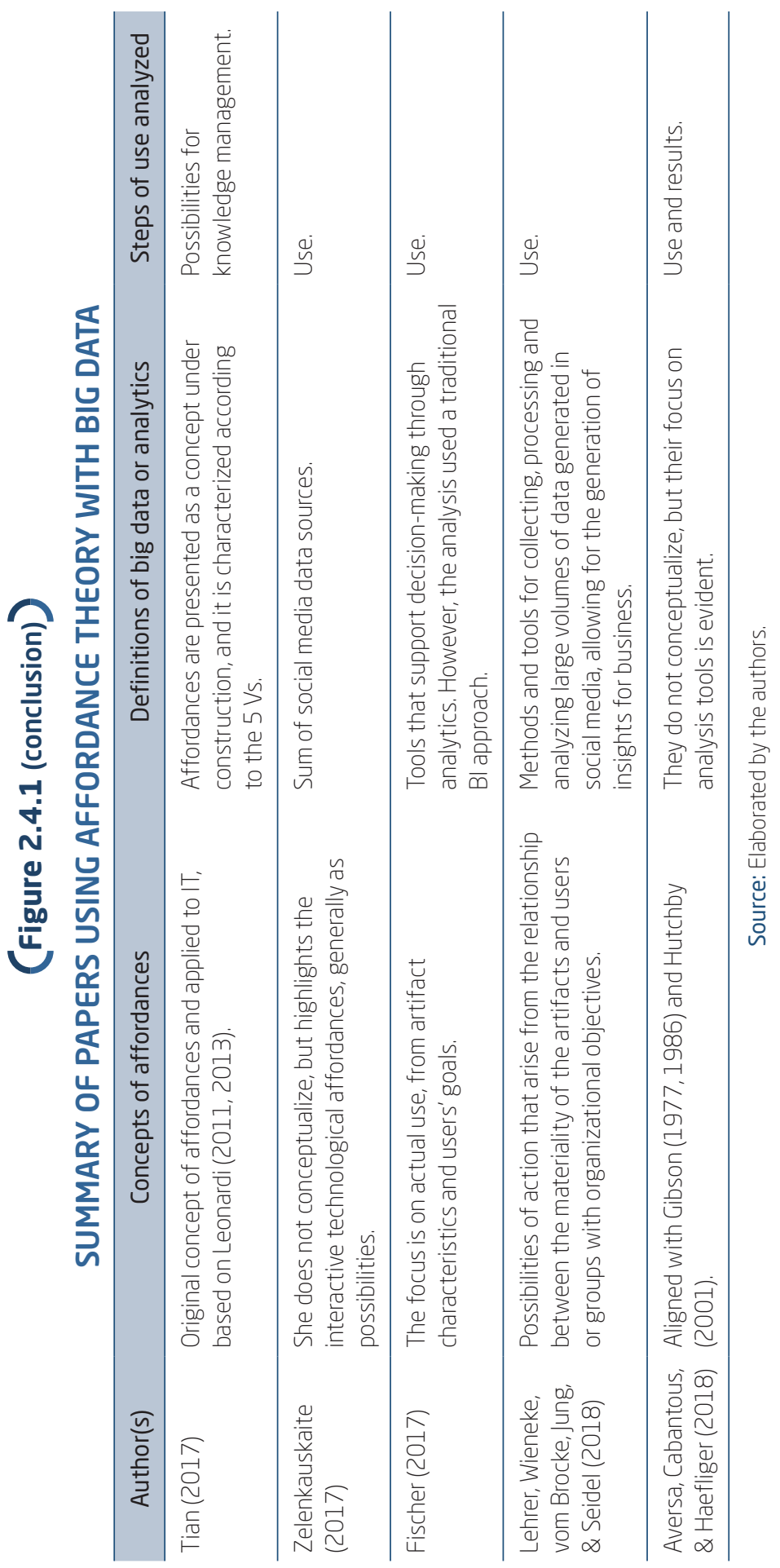


Figure 2.4.1 shows that the definitions of big data and analytics have some variations, depending on the intended use or the area to be analyzed. While some authors focus on the characteristics (Etzion \& Aragon-Correa, 2016; Williams, Burnap, \& Sloan, 2017), others highlight the techniques (Hansen \& Flyverbom, 2015; Madsen, 2015) and the processes. Dremel et al. (2017), in turn, consider the four sociotechnical perspectives and portray big data as tasks made possible by technologies, actors and structures, which allow for the collection and analysis of data and improve decision-making, aligned with the concept of Abbasi et al. (2016).

Regarding the concept of affordance, differences are also observed, although only two do not explicitly cite Gibson's original theory. Etzion and Aragon-Correa (2016), for example, even without citing this source, align their interpretation with the theory. However, Williams et al. (2017) deal with affordances as features, something that Gibson $(1977,1986)$ explicitly stated as not being the case. Madsen (2015) also highlights affordance characteristics, but the author uses them as a starting point to analyze how they are applied in different contexts.

Some authors define affordances not only as possibilities for action but also as constraints or difficulties imposed by technology (Hansen \& Flyverbom, 2015; Koch \& Peters, 2017). In this case, the design or features of an artifact can be interpreted as signs that could be observed by users (or organizations). Design or features can make their affordances explicit, or keep some hidden (Gibson, 1977). This is because systems or technologies are created for a purpose. But how people will behave when using them cannot be entirely determined; they may even have surprising applications (Hansen \& Flyverbom, 2015). Although none of the papers reviewed delves deeper into this question, it may be important to investigate the context of big data, since, as stated in the introduction, technologies have been around for decades, but implementation in organizations has only been of interest in recent years.

The other papers, in addition to Hutchby (2001) and Markus and Silver (2008), use Gibson $(1977,1986)$ as a theoretical foundation. Fischer (2017) emphasizes that the focus must be on actual, and not just potential, use. He states that people act according to features of the tool that trigger such actions. These features are the clues to what the artifact contains, helping users to realize its potential uses. Dremel et al. (2017) also work with the process of transforming perceived affordances into accomplished affordances. The authors seek to understand the process that makes organizations realize and actually use big data analytics tools, identifying changes in structure, people, technology and actions that have led to a new way of doing things. Their research is still in progress and converges with what our essay 
proposes, that is, an analysis beyond the stage of perception and the start of using affordances.

\section{ANALYSIS OF THE LITERATURE ON AFFORDANCES AND THE USE OF BIG DATA AND ANALYTICS}

Affordance theory has been adopted to understand the process of using IT artifacts (Hutchby, 2001; Markus \& Silver, 2008), in particular, its results, i.e., how affordances are actualized (Strong et al., 2014). Among the texts analyzed, only the research in progress from Dremel et al. (2017) deals with the process of using big data analytics through the affordance lens, and how this leads organizations to take advantage of it. The authors are analyzing the automotive sector because they consider that, for each organization and environment profile, type of problem to be solved, and adopted technology of big data analytics, there is a distinct process of cognition, recognition, behavior and affordances effects.

In this essay, the framework presented in Figure 2.2.1 was selected as a starting point for analyzing the use of big data analytics. Within this framework, the disruptive elements of the information value chain (Abbasi et al., 2016) are present both in technologies and in organizations (people, processes, and structure). There are those elements that go through a process of affordance perception, from symbolic expressions or clues about the design of the artifact.

In this sense, it is necessary to understand how this perception happens or is generated. Even if the area of IT has developed different constructs of affordances, this question is still not well understood. Parchoma (2014) suggests that ANT can contribute to understanding how enablers, constraints, and rules emerge from the temporal relationship between physical, cultural and organizational aspects. This temporal analysis is consistent with the framework in Figure 2.2.1. In addition, ANT is useful for analyzing processes (De Camillis \& Antonello, 2016).

Parchoma (2014) does not indicate which ANT elements could be useful. However, the ANT translation process seems to be particularly useful because it deals with moments and actors by which a network organizes itself. The moments of translation are problematization, interessement, enrolment, and mobilization (Callon, 1984; Soares \& Joia, 2018), which are defined as follows:

- Problematization: How to become indispensable? At this stage, the main actor identifies the problem and objective, as well as the obligatory passage points and which goal should be achieved. 
- Interessement: When the main actor searches for allies and a group of actions to achieve the goal.

- Enrolment: At this point, the roles are distributed among all actors who have agreed to participate in the achievement of the proposed goal in the course of problematization.

- Mobilization: When the spokespeople are representative, and also when changes are made in the network.

Affordance theory requires a signal or trigger to perceive the affordances. Perhaps this trigger can be started by the main actor during problematization. Callon (1984) makes it clear that, in the process of translation, actors do not always engage at first, but rather as actions take place. In the same way, goals can change over time, while the engagement of actors can occur for their own purposes. However, to stabilize the network, or for the affordances to have an organizational effect, a spokesperson may be needed. This is aligned with affordances, as actors can have their own goals when using a particular technology, as well as find other uses for this technology.

The following section presents a case - illustrative rather than complete in order to verify whether the affordance process-based framework, combined with the ANT translation elements, has the potential to explain the use of big data and analytics.

\section{ILlUSTRATIVE CASE}

The organization selected for this analysis started a BI implementation project in 2015 and, since 2018, has been deploying analytics solutions. The organization's business is educational credit and operates throughout Brazil. Clients are students and teaching institution partners, as well as companies that support the education of their employees. The organization is responsible for managing the entire process, starting with the contracts and carrying out payment collection on these contracts.

Once the organization was contacted, we searched for secondary data on its website and interviewed the person responsible for the BI tool implementation project. The interview lasted 46 minutes. Next, we visited the dependencies of the organization, in order to observe some of the BI panels. We also met other people participating in the implementation project for analytics and predictive tools, including the chief data scientist.

The implementation of a BI tool was the idea of the interviewee. The goal was to replace existing reports, extracted from transactional systems, with something more dynamic and requiring fewer IT staff hours to develop 
ad hoc solutions. The idea was, in the words of the interviewee, "bought" by the director, meaning it had support from the leadership. A BI tool has been chosen to display data in web browsers and mobile devices.

The implementation process took place with the support of a specialized company. The team was formed by both IT professionals and business analysts, as well as key users or BI analysts. According to the interviewee:

When we chose BI analysts, they were people who were not decision makers, and we picked the right people: people who were motivated, who know they are more engaged $[\ldots]$, these people adhered very well, from the beginning.

People with business knowledge and, more importantly, who were motivated and had available time were selected. In addition, the tool proved to be productive, which made it possible to deliver information in a shorter time. As the tool was providing new indicator views, users began to see other possibilities for analysis and request new dashboards.

After a year and a half of designing and using BI, the project moved to a bigger dimension, and people began to "turn the key". In other words, there was a change in the way of making decisions and analyzing problems and indicators. To explain this "turn", the interviewee commented that:

From one year to a year and a half from now [...] people began to look, to be interested, managers started to attend meetings and began to set up committees. And then, what happened? Oh, the number of debtors was so high. When this type of information was reported [...] the commercial area, the accounting people, the legal representatives, everyone felt uncomfortable. Then we started putting the staff together, to set up a committee, to assemble visions that were common to all, because this information had to be released. And information is an important thing, everyone must agree with that information. So [...] the first moment hurt, but then the process began to gain the participation of managers, of coordinators, and more and more people were found to be engaged.

With those statements, we can observe that the technology, which was initially implemented with the specific objective of improving the productivity of the IT team, began to make other uses possible (Leonardi, 2011), in turn motivating people to search for new analysis tools. However, to do this, it was necessary to convince and teach people and release concrete results as well as share knowledge and consolidate indicators. At the time of the interview, the organization already had a new team, involving its own staff 
and a consultancy in the field of data science. This team is defining new indicators and developing predictive analyzes. The analysis of the affordance process and the moments of translation is summarized in Figure 4.1.

\section{(Figure 4.1)}

\begin{tabular}{c} 
PROCESS OF USING BIG DATA AND ANALYTICS IN THE ORGANIZATION \\
\hline \multicolumn{2}{c}{ Affordances process } \\
\multicolumn{2}{c}{ Existence of affordances } \\
\hline
\end{tabular}

\begin{tabular}{|c|c|c|}
\hline $\begin{array}{l}\text { Big data and } \\
\text { analytics } \\
\text { platforms }\end{array}$ & Nonexistent in the organization. & \multirow[t]{4}{*}{$\begin{array}{l}\text { Problematization: the main actor, an } \\
\text { IT analyst, identified the need to } \\
\text { generate reports more dynamically. }\end{array}$} \\
\hline People & $\begin{array}{l}\text { IT team with SQL knowledge; business } \\
\text { analysts. }\end{array}$ & \\
\hline Processes & $\begin{array}{l}\text { Reports generated manually from requesting } \\
\text { users, which should be accurate to contain the } \\
\text { required data. }\end{array}$ & \\
\hline Structure & $\begin{array}{l}\text { IT staff for development and analysts for } \\
\text { specific analyses. }\end{array}$ & \\
\hline \multicolumn{3}{|c|}{ Perception } \\
\hline $\begin{array}{l}\text { Symbolic } \\
\text { expressions }\end{array}$ & $\begin{array}{l}\text { Knowledge acquired by the interviewee on an } \\
\text { undergraduate program; search for tools on } \\
\text { the market. }\end{array}$ & \multirow[t]{2}{*}{$\begin{array}{l}\text { Interessement: the board buys the } \\
\text { idea, authorizing the acquisition of a } \\
\text { Bl tool. }\end{array}$} \\
\hline Design & Experimentation of demo versions. & \\
\hline \multicolumn{3}{|c|}{ Actualization } \\
\hline \multirow{5}{*}{$\begin{array}{l}\text { Action } \rightarrow \\
\text { immediate } \\
\text { outcomes }\end{array}$} & $\begin{array}{l}\text { Generation of reports from the new tool } \rightarrow \\
\text { Reduction in the delivery time of new reports. }\end{array}$ & \multirow{5}{*}{$\begin{array}{l}\text { Engagement: initial activities } \\
\text { involved analysts, IT staff, and key } \\
\text { users. After the first results, } \\
\text { managers actively became involved. } \\
\text { It was necessary to negotiate the } \\
\text { meaning of indicators. The design of } \\
\text { the generated artifacts } \\
\text { (dashboards) allowed users' } \\
\text { autonomy and different views on } \\
\text { the same data. The director was the } \\
\text { main sponsor of the project. }\end{array}$} \\
\hline & $\begin{array}{l}\text { Creation of dashboards } \rightarrow \text { automatic } \\
\text { generation of data. } \\
\text { Creation of dashboards } \rightarrow \text { autonomy of } \\
\text { analysis by users. }\end{array}$ & \\
\hline & $\begin{array}{l}\text { Dissemination of consolidated data to the } \\
\text { whole organization } \rightarrow \text { interest in } \\
\text { understanding the results and acting on them. }\end{array}$ & \\
\hline & $\begin{array}{l}\text { Provision of displays with dashboards per area } \\
\rightarrow \text { direct monitoring of teams and managers. }\end{array}$ & \\
\hline & $\begin{array}{l}\text { Automation of reporting } \rightarrow \text { change in IT staff } \\
\text { profile. }\end{array}$ & \\
\hline
\end{tabular}

\begin{tabular}{|c|c|c|}
\hline People & $\begin{array}{l}\text { IT team with SQL knowledge; business } \\
\text { analysts. }\end{array}$ & \\
\hline Processes & $\begin{array}{l}\text { Reports generated manually from requesting } \\
\text { users, which should be accurate to contain the } \\
\text { required data. }\end{array}$ & \\
\hline Structure & $\begin{array}{l}\text { IT staff for development and analysts for } \\
\text { specific analyses. }\end{array}$ & \\
\hline \multicolumn{3}{|c|}{ Perception } \\
\hline $\begin{array}{l}\text { Symbolic } \\
\text { expressions }\end{array}$ & $\begin{array}{l}\text { Knowledge acquired by the interviewee on an } \\
\text { undergraduate program; search for tools on } \\
\text { the market. }\end{array}$ & \multirow[t]{2}{*}{$\begin{array}{l}\text { Interessement: the board buys the } \\
\text { idea, authorizing the acquisition of a } \\
\text { Bl tool. }\end{array}$} \\
\hline Design & Experimentation of demo versions. & \\
\hline \multicolumn{3}{|c|}{ Actualization } \\
\hline \multirow{7}{*}{$\begin{array}{l}\text { Action } \rightarrow \\
\text { immediate } \\
\text { outcomes }\end{array}$} & Generation of reports from the new tool $\rightarrow$ & \multirow{7}{*}{$\begin{array}{l}\text { Engagement: initial activities } \\
\text { involved analysts, IT staff, and key } \\
\text { users. After the first results, } \\
\text { managers actively became involved. } \\
\text { It was necessary to negotiate the } \\
\text { meaning of indicators. The design of } \\
\text { the generated artifacts } \\
\text { (dashboards) allowed users' } \\
\text { autonomy and different views on } \\
\text { the same data. The director was the } \\
\text { main sponsor of the project. }\end{array}$} \\
\hline & Reduction in the dellvery tim & \\
\hline & $\begin{array}{l}\text { Creation of dashboards } \rightarrow \text { automatic } \\
\text { generation of data. }\end{array}$ & \\
\hline & $\begin{array}{l}\text { Creation of dashboards } \rightarrow \text { autonomy of } \\
\text { analysis by users. }\end{array}$ & \\
\hline & $\begin{array}{l}\text { Dissemination of consolidated data to the } \\
\text { whole organization } \rightarrow \text { interest in } \\
\text { understanding the results and acting on them. }\end{array}$ & \\
\hline & $\begin{array}{l}\text { Provision of displays with dashboards per area } \\
\rightarrow \text { direct monitoring of teams and managers. }\end{array}$ & \\
\hline & $\begin{array}{l}\text { Automation of reporting } \rightarrow \text { change in IT staff } \\
\text { profile. }\end{array}$ & \\
\hline
\end{tabular}

Problematization: the main actor, an IT analyst, identified the need to generate reports more dynamically. 
(Figure 4.1 (conclusion))

\begin{tabular}{l} 
PROCESS OF USING BIG DATA AND ANALYTICS IN THE ORGANIZATION \\
\multicolumn{1}{c}{ Affordances process } \\
\begin{tabular}{ll}
\multicolumn{1}{c}{ Effect } & Translation moments \\
\hline $\begin{array}{l}\text { Creation of data analysis committees; use of dashboards and } \\
\text { information in strategic planning; }\end{array}$ & $\begin{array}{l}\text { Mobilization: the director as the } \\
\text { spokesman on the use of big data } \\
\text { and analytics, with the analysis } \\
\text { Training of staff to generate predictive analysis. }\end{array}$ \\
& committees. People who did not \\
& adapt are no longer in the \\
& organization.
\end{tabular} \\
\hline
\end{tabular}

Source: Elaborated by the authors.

The big data and analytics platform was not part of the organization's IT portfolio. However, needs raised by the primary actor (problematization) and big data gained the support of the director (interessement), after which a tool was acquired. From that moment, the organization entered the actualization phase of affordances.

The implementation and use of IT tools provoke sociotechnical changes in an organization (Dremel et al., 2017). In this case, the affordances that initially exist in the BI tool was limited to the ability to extract data from a variety of internal sources and provide reports and dashboards quickly and in a visually attractive manner. With engagement, there was a redistribution of roles, and the first outcomes generated analytical autonomy for analysts and managers. In addition, the negotiation and consolidation of previously undisclosed indicators led to a change in management attitudes, which resulted in the creation of committees for the joint analysis of problems, more data-based and facts-based planning, and a new profile for managers. Finally, other affordances were perceived by the organization, with the possibility to analyze, in the near future, external sources and unstructured data and to perform predictive analysis, as well as initiating a new round of problematization and, with it, a new cycle of affordances.

\section{FINAL CONSIDERATIONS}

Big data and analytics tools have existed for over two decades. More recently, interest in research has grown, as has the interest in organizations to implement them. Given the observed gap between the development of 
tools and their use, support was sought from affordance theory to understand how the deployment and use process occurs.

We analyzed basic papers and articles that had adopted the affordance theory to explain the use or possibilities of employing big data and analytics. The process view has proven to be a viable lens for understanding adoption and use, at both the individual and the organizational levels. Affordance theory provides a basis for the analysis of the imbrication between technology and humans and offers evidence for the possibilities and advantages of IT tools and their environment of use in the organization - people, processes and structures - as well as constraints or disadvantages. We included the affordances process (Strong et al., 2014) and the translation of the ANT into the initial framework (Figure 2.2.1). An illustrative case study was conducted to ascertain the usefulness of these inclusions. Some of the categories in affordance theory and ANT translation could be mapped, e.g. the actions in the actualization stage and its immediate outcomes. On the other hand, organizational results, here called "effects of affordances", were also observed and, from them, the perception of new affordances, indicating the recursiveness of the process on several levels.

The proposed framework (Figure 5.1) aims to better support the study of the close relations (imbrications) between humans, IT, organizations and communication processes, as well as the adoption and recursivity necessary for the comprehensive exploitation of the potential offered by big data and analytics. The dotted arrows represent the idea of a cycle, whereas the continuous lines represent a temporal idea. 


\section{(Figure 5.1)}

\section{FRAMEWORK OF BIG DATA AND ANALYTICS AFFORDANCE TRANSLATION ANALYSIS}

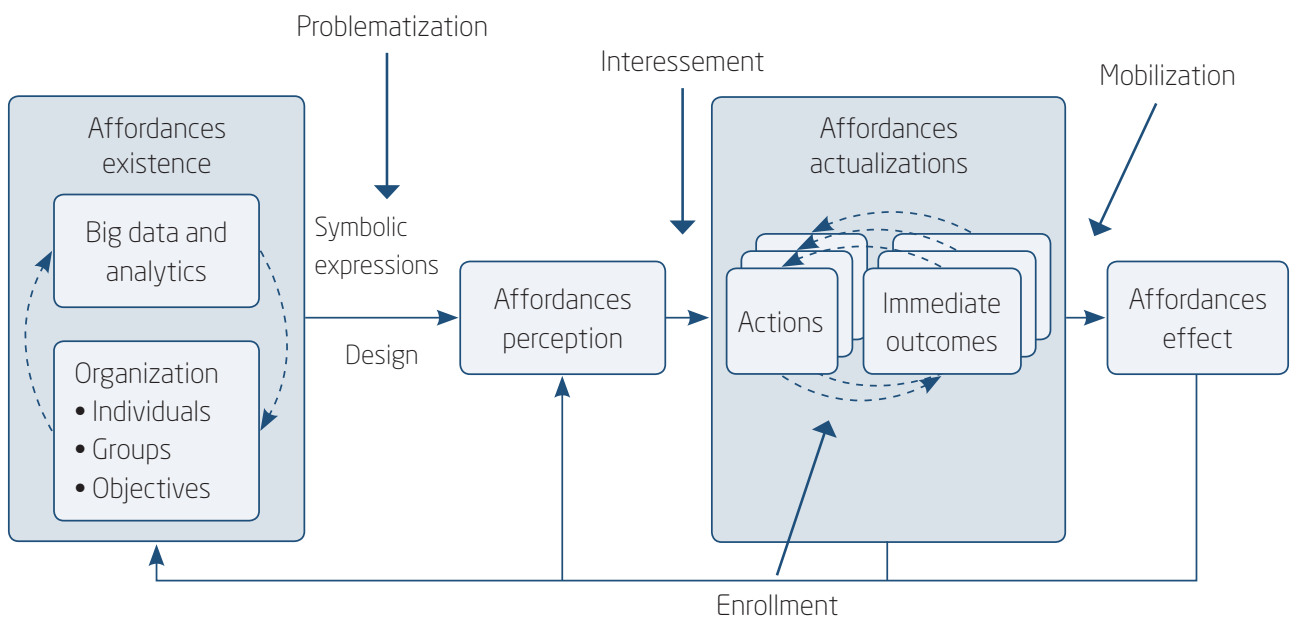

Source: Elaborated by the authors.

In the proposed framework, we included the elements of translation (Callon, 1984). Although these elements are aligned with the process of transforming existing or potential into perceived and actualized affordances and their effects, it is not simply a question of inserting a new label at each step, but rather one of introducing an important concept of ANT as the theoretical lens through which to understand how affordances move and evolve through the stages.

Although affordances exist, they must be recognized and information about the artifact must be available. This recognition may occur through cues about the design or features offered by the artifact (Norman, 1999) or by other groups and people, information external to the organization, symbolic expressions (Markus \& Silver, 2008) etc. In the proposed framework, it is in this phase that problematization occurs, and the following questions must be analyzed:

- Who are the actors involved? In particular, who is the main actor?

- What is the obligatory passage point that will ensure the perception of the affordances?

At this point, interessement begins. Each actor can now be part of the initial plan or not (Callon, 1984); if so, each actor can overcome the possible 
difficulties inherent in technological or social affordances. Further, the actualization of affordances concerns the process of using and interacting with the artifact and potentializing its affordances (Strong et al., 2014). This actualization is a concrete action on the part of individuals or groups of individuals who are taking advantage of the technology in order to achieve a goal by analyzing the immediate outcome. Such an individual action, as legitimized by the groups, begins to incorporate routines at the organizational level. The process of engagement, meaning how roles are defined and coordinated, including negotiations, attempts, strengths and tricks (Callon, 1984), can explain how affordances are actualized.

Finally, the affordance effect is the organizational result from the use of big data and analytics. This effect can be analyzed through mobilization, when the network is accepted (Soares \& Joia, 2018). At this stage, it is important to know who the process spokespeople are and if they are representative.

In conclusion, the final framework is expected to be practical for research purposes. When it was originated, Bernhard et al. (2013) highlighted the difference between the four main explicit elements, as they had been conceptualized as stages in a recursive process. While the authors themselves stated that affordances must be actualized, the necessary effort for that to happen is still not well understood. With the proposed insertion of the translation concept of ANT in our framework, negotiations and human and nonhuman actors and actions could be better understood, in particular, in terms of how the whole process occurs in its four stages.

The main limitation of this study is the empirical analysis presented. The case described was not intended to be a complete case study, but to serve as an example for verification of the elements of the proposed framework. Therefore, to consolidate this framework, more in-depth and longitudinal studies should be performed.

\section{PROPOSTA DE FRAMEWORK PARA ANÁLISE DAS AFFORDANCES QUANDO DO USO DE BIG DATA E ANALYTICS NAS ORGANIZAÇÕES}

\section{RESUMO}

Objetivo: O artigo apresenta o desenvolvimento de um framework para analisar como ocorre o uso de big data e analytics nas organizações, o qual está baseado na teoria das affordances e na teoria ator-rede (TAR). 
Originalidade/valor: Big data e analytics, mesmo usando ferramentas e técnicas que não são novas, têm recebido muita atenção da mídia especializada em TI e da academia, a primeira para fomentá-la e a segunda porque ainda existem dificuldades de implantação e o processo de uso de big data analytics não é bem compreendido.

Design/metodologia/abordagem: O trabalho tem uma abordagem qualitativa, na forma de um ensaio teórico. Analisaram-se trabalhos que relacionaram a teoria das affordances com TI e com big data e analytics, e, para propor o framework resultante, além de contribuições da TAR, foi conduzido um estudo de caso ilustrativo.

Resultados: A teoria das affordances aliada à translação da TAR pode ser útil para aanálise do processo de uso de big data e analytics em organizações, pois contempla aspectos individuais e organizacionais, abrangendo a percepção de utilidade, as transformações sociotécnicas necessárias em processos, pessoas e estruturas, a utilização de fato e os efeitos organizacionais. Como contribuição, foi proposto um framework que inclui elementos de translação da TAR para guiar pesquisas futuras.

\section{PALAVRAS-CHAVE}

Big data. Analytics. Affordances. Teoria ator-rede. Framework.

\section{$\int$ REFERENCES}

Abbasi, A., Sarker, S., \& Chiang, R. H. L. (2016). Big data research in information systems: Toward an inclusive research agenda. Journal of the Association of Information Systems, 17(2), 1-32.

Aversa, P., Cabantous, L., \& Haefliger, S. (2018). When decision support systems fail: Insights for strategic information systems from Formula 1. Journal of Strategic Information Systems, 27(3), 221-236. doi:10.1016/j.jsis. 2018.03.002

Bernhard, E., Recker, J., \& Burton-Jones, A. (2013). Understanding the actualization of affordances: A study in the process modeling context. Proceedings of the International Conference on Information Systems, Milan, Italy, 34.

Boyd, D., \& Crawford, K. (2012). Critical questions for big data. Information, Communication \& Society, 15(5), 662-679. doi:10.1080/1369118X.2012. 678878 
Callon, M. (1984). Some elements of a sociology of translation: Domestication of the scallops and the fishermen of St Brieuc Bay. The Sociological Review, 32 (suppl. 1), 196-233.

Chen, H., Chiang, R. H. L., \& Storey, V. C. (2012). Business intelligence and analytics: From big data to big impact. MIS Quarterly, 36(4), 1165-1188. doi: $10.2307 / 41703503$

CIO (2016). Menos empresas estão investindo mais em big data, afirma Gartner. Recuperado de http://cio.com.br/tecnologia/2016/12/01/menosempresas-estao-investindo-mais-em-big-data-afirma-gartner

Coimbra, M. R., \& Chimenti, P. C. P. de S. (2018). Big data e algoritmos: Aplicações e temas em debates resumo. Proceedings of Encontro da Anpad, Curitiba, PR, Brasil, 42.

Couldry, N. (2014). A necessary disenchantment: Myth, agency and injustice in a digital world. The Sociological Review, 62 (4), 880-897. doi:10.1111/1467954X.12158

Davenport, T. H. (2013). Analytics 3.0. Harvard Business Review, Dec., 64-72.

Davenport, T. H. (2014). Big data no trabalho: Derrubando mitos e descobrindo oportunidades. Rio de Janeiro: Elsevier.

De Camillis, P. K., \& Antonello, C. S. (2016). Da translação para o enactar: contribuições da teoria ator-rede para a abordagem processual das organizações. Cadernos Ebape.BR, 14(1), 61-82.

Dremel, C., Herterich, M. M., \& Spottke, B. (2017). Actualizing affordances: A socio-technical perspective on big data analytics in the automotive sector. Proceedings of International Conference on Information Systems, Seoul, South Korea, 38.

Etzion, D., \& Aragon-Correa, J. A. (2016). Big data, management, and sustainability. Organization \& Environment, 29(2), 147-155. doi:10.1177/ 1086026616650437

Fischer, T. C. (2017). Gamification and affordances: How do new affordances lead to gamification in a business intelligence system? In J. Stolfa, S. Stolfa, R. V. O'Connor, \& R. Messnarz. Systems, software and services process improvement. London: Springer. doi:10.1007/978-3-319-64218-5

Germann, F., Lilien, G. L., \& Rangaswamy, A. (2013). Performance implications of deploying marketing analytics. International Journal of Research in Marketing, 30(2), 114-128. doi:10.1016/j.ijresmar.2012.10.001

Gibson, J. J. (1977). The theory of affordances. In R. Shaw \& J. Bransford (Orgs.). Perceiving, acting and knowing (pp. 67-82). New Jersey: John Wiley \& Sons. 
Gibson, J. J. (1986). The ecological approach to visual perception. New Jersey: Taylor \& Francis Group.

Hansen, H. K., \& Flyverbom, M. (2015). The politics of transparency and the calibration of knowledge in the digital age. Organization, 22 (6), 872-889. doi: $10.1177 / 1350508414522315$

Hutchby, I. (2001). Technologies, texts and affordances. Sociology, 35(2), 441-456. doi:10.1017/S0038038501000219

Klecun, E., Hibberd, R., \& Lichtner, V. (2016). Affordance theory perspectives on IT and healthcare organization. Proceedings of International Conference on Information Systems, Dublin, Ireland, 37.

Koch, H., \& Peters, U. (2017). Shadow analytics. Proceedings of Americas Conferences on Information Systems, Boston, United States, 23.

Latour, B. (2012). Reagregando o social: Uma introdução à teoria do ator-rede. Salvador: Edufba; Bauru: Edusc.

Lehrer, C., Wieneke, A., Brocke, J. vom, Jung, R., \& Seidel, S. (2018). How big data analytics enables service innovation: Materiality, affordance, and the individualization of service. Journal of Management Information Systems, 35(2), 424-460. doi: 10.1080/07421222.2018.1451953

Leonardi, P. M. (2011). When flexible routines meet flexible technologies: Affordance, constraint, and the imbrication of human and material agencies. MIS Quarterly, 35(1), 147-167. doi:10.2307/23043493

Leonardi, P. M. (2013). When does technology use enable network change in organizations? A comparative study of feature use and shared affordances. MIS Quarterly, 37(3), 749-775.

Luvizan, S. S., Meirelles, F. S., \& Diniz, E. H. (2015). Big data: Evolução das publicações e oportunidades de pesquisa. Revista Eletrônica de Sistemas de Informação, 14(3). doi:10.21529/RESI.2015.1403003

Madsen, A. K. (2015). Between technical features and analytic capabilities: Charting a relational affordance space for digital social analytics. Big Data E Society, 2(1), 1-15. doi:10.1177/2053951714568727

Markus, M. L., \& Silver, M. S. (2008). A foundation for the study of IT effects: A new look at DeSanctis and Poole's concepts of structural features and spirit. Journal of the Association for Information Systems, 9(10), 609-632.

McCosker, A. (2017). Social media work: Reshaping organisational communications, extracting digital value. Media International Australia, 163(1), 122-136. doi:10.1177/1329878X17693702 
Müller, O., Junglas, I., Brocke, J. vom, \& Debortoli, S. (2016). Utilizing big data analytics for information systems research: Challenges, promises and guidelines. European Journal of Information Systems, 25(4), 289-302. doi:10. 1057/ejis.2016.2

Norman, D. (1999). Affordances, conventions and design. Interactions, 6(3), 38-42.

Parchoma, G. (2014). The contested ontology of affordances: Implications for researching technological affordances for collaborative knowledge production. Computers in Human Behavior, 37, 360-368. doi:10.1016/j.chb. 2012.05.028

Pozzi, G., Pigni, F., \& Vitari, C. (2014). Affordance theory in the IS discipline: A review and synthesis of the literature. Americas Conference on Information Systems, Savannah, USA, 20.

PWC. (2017). The human factor: Working with machines to make big decisions. Recuperado de from www.pwc.com/bigdecisions

Ross, J. W., Beath, C. M., \& Quaadgras, A. (2013). You may not need big data after all. Harvard Business Review, Dec., 90-98.

Soares, C. D. M., \& Joia, L. A. (2018). As redes sociais e a manifestação "20 Centavos" no Brasil sob a ótica da teoria ator-rede. Anais do Encontro da ANPAD, Curitiba/Paraná, 42.

Strong, D. M., Johnson, S. A., Trudel, J., Pelletier, L. R., Bar-on, I., \& Garber, L. (2014). A theory of organization-EHR affordance actualization. Journal of the Association for Information Systems, 15(2), 53-85.

Tian, X. (2017). Big data and knowledge management: A case of déjà vu or back to the future? Journal of Knowledge Management, 21 (1), 113-131. doi:10.1108/JKM-07-2015-0277

Volkoff, O., \& Strong, D. (2013). Critical realism and affordances: Theorizing IT-associated organizational change processes. MIS Quarterly, 37(3), 819-834.

Wang, H., Wang, J., \& Tang, Q. (2018). A review of application of affordance theory in information systems. Journal of Service Science and Management, 11 (01), 56-70. doi:10.4236/jssm.2018.111006

Werkhoven, J. A. (2017). Exploring functional affordances and sensemaking in human resource analytics full paper. Americas Conference on Information Systems, Boston, USA, 23.

Williams, M. L., Burnap, P., \& Sloan, L. (2017). Crime sensing with big data: The affordances and limitations of using open-source communications to estimate crime patterns. British Journal of Criminology, 57(2), 320-340. doi:10.1093/bjc/azw031 
Zammuto, R. F., Griffith, T. L., Majchrzak, A., Dougherty, D. J., \& Faraj, S. (2007). Information technology and the changing fabric of organization. Organization Science, 18(5), 749-762. doi:10.1287/orsc.1070.0307

Zelenkauskaite, A. (2017). Remediation, convergence, and big data. Convergence, 23(5), 512-527. doi:10.1177/1354856516631519

\section{AUTHOR NOTES}

Luisa M. Strauss, Escola de Administração, Universidade do Vale do Rio dos Sinos (Unisinos); and Norberto Hoppen, Institut d'Administration des Entreprises, Université Pierre MendèsFrance Grenoble.

Luisa M. Strauss is now PhD student at Unisinos Business School at Universidade do Vale do Rio dos Sinos (Unisinos); and Norberto Hoppen is now professor at Unisinos Business School at Universidade do Vale do Rio dos Sinos (Unisinos).

Correspondence concerning this article should be addressed to Luisa M. Strauss, Avenida Nilo Peçanha, 1600, Bela Vista, Porto Alegre, Rio Grande do Sul, Brazil, CEP: 91330-002.

E-mail: lustrauss@gmail.com

EDITORIAL BOARD

Editors-in-chief

Janette Brunstein

Silvia Marcia Russi de Domênico

Associated Editor

Thais Vick

Technical Support

Vitória Batista Santos Silva

EDITORIAL PRODUCTION

Publishing Coordination

Jéssica Dametta

Language Editor

Daniel de Almeida Leão
Layout Designer

Emap

Graphic Designer

Libro 